\title{
PENDAMPINGAN STRATEGI BISNIS, PEMASARAN DARING DAN PELAPORAN KEUANGAN PADA RINTISAN UMKM
}

\author{
Akhmad Solikin ${ }^{1)}$; Raditya Hendra Pratama ${ }^{2)}$; Azas Mabrur ${ }^{3)}$ \\ 1)akhsol@pknstan.ac.id, Politeknik Keuangan Negara STAN* \\ 2) h3ndra@pknstan.ac.id, Politeknik Keuangan Negara STAN \\ n) azas.mabrur@pknstan.ac.id, PoliteknikKeuangan Negara STAN \\ * untuk penulis korespondensi
}

\begin{abstract}
Micro, small and medium enterprises are important business entities in Indonesia, albeit facing several problems to expand their businesses. This community empowerment activity aims at solving those problems, especially in terms of business strategy, online marketing, and financial reporting. The community empowerment activity was implemented in three steps, i.e. preparation, technical guidance, and accompaniment. From problem identification in the registration process, three topics were selected for technical guidance, i.e. business strategy, online marketing via social media, and financial statement preparation. Topic on capital, albeit faced by several micro and small entrepreneurs, did not discussed in the community empowerment activity. Recapitulaion results of evaluation show that participants in general score learning materials and facilitators in the technical guidance were very good. After technical guidance, in a month the participants are accompanied to apply knowledge acquired during the technical guidance.
\end{abstract}

Keywords: Business Model Canvas, Business Strategy, Small Mediun Enterprise, Online marketing, Lamikro

\begin{abstract}
Abstrak
UMKM merupakan entitas usaha yang penting di Indonesia, walaupun perkembangan usahanya menghadapi berbagai masalah. Kegiatan pengabdian masyarakat ini bertujuan untuk mengatasi masalah-masalah tersebut, khususnya dari sisi strategi bisnis, pemasaran daring, dan penyusunan laporan keuangan. Pengabdian masyarakat ini dilakukan dalam tiga tahap yaitu persiapan, bimbingan teknis, dan pendampingan. Dari hasil identifikasi masalah pada tahap persiapan dipilih tiga topik untuk bimbingan teknis yaitu strategi bisnis, pemasaran online lewat media sosial, dan penyusunan laporan keuangan. Topik tentang permodalan, meskipun dihadapi oleh sebagian pengusaha UMKM, tidak dibahas pada kegiatan pengmas ini. Hasil rekapitulasi evaluasi menunjukkan bahwa peserta menilai materi dan pemateri dalam bimbingan teknis tersebut sangat baik. Setelah dilakukan bimbingan teknis, selama sebulan peserta didampingi untuk mengaplikasikan pengetahuan yang diperoleh dalam bimbingan teknis.
\end{abstract}

Kata Kunci: Business Model Canvas, UMKM, Strategi bisnis, Pemasaran online, Lamikro

\section{PENDAHULUAN}

Berdasarkan data Kementerian Koperasi dan UMKM (2021) pada tahun 2018 terdapat 64,2 juta Usaha Mikro Kecil Menengah (UMKM) atau dengan kata lain dari keseluruhan unit usaha di Indonesia sekitar 99\% merupakan UMKM; yang berkontribusi 61,07 persen terhadap PDB. Dari sisi ketenagakerjaan, UMKM menyerap sebagian besar tenaga kerja, yaitu 97\%; serta berkontribusi pada 60,42 persen investasi di Indonesia.

Kekuatan UMKM inilah yang menjadi sebab semua pihak menyorot dan berharap UMKM agar dapat bertahan menghadapi kondisi krisis di masa pandemi Covid-19. Potensi peningkatan angka pengangguran dan kemungkinan peningkatan kredit macet adalah hal yang membayangi UMKM, sehingga diperlukan perhatian lebih untuk UMKM. Jika tidak diperhatikan maka akan ada potensi sektor perekonomian lokal terganggu yang dapat berdampak pada perekonomian secara nasional.

Salah satu strategi pemerintah dalam rangka mengurangi dampak ekonomi di kala pandemi Covid-19 ini adalah dengan meluncurkan program yang disebut Program Pemulihan Ekonomi nasional (PEN). Program tersebut salah satunya bertujuan untuk melindungi, mempertahankan, dan meningkatkan kemampuan ekonomi para pelaku usaha dalam menjalankan usaha di masa pandemi Covid-19. Bagi UMKM, program PEN diharapkan dapat meringankan beban UMKM serta meningkatkan kontribusi dan kinerja sehingga membawa dampak positif terhadap perekonomian Indonesia. Pada tahun 2020, anggaran yang telah 
dipersiapkan Rp695 triliun; Rp123,45 triliun dialokasikan untuk UMKM (Purwanto 2020). Hingga Desember 2020, anggaran untuk UMKM yang telah disalurkan Rp87,08 triliun atau sebesar 70,37\% dari pagu yang ditetapkan (Kemenkop UKM, 2020).

Meskipun demikian, tingkat keberhasilan dari UMKM untuk bertahan dan berkembang sangat terbatas. Tanpa adanya wabah Covid-19 pun, tingkat keberhasilan rintisan UMKM sangat rendah; apalagi dengan kondisi ekonomi yang memburuk akibat wabah Covid-19. Wabah Covid-19 memengaruhi UMKM karena: (1) konsumen memilih untuk membatasi belanja, (2) kesulitan mencari bahan baku, (3) kenaikan harga bahan baku, (4) perubahan selera konsumen ke produk kuliner daripada fashion dan kriya, (5) kurangnya pemasaran online, (6) tergantung pada pusat perbelanjaan yang tutup ketika pandemi (Hertina et al., 2021).

UMKM memiliki peranan penting dalam meningkatkan kemajuan perekonomian di Indonesia. Namun, UMKM memiliki beberapa permasalahan, salah satunya dalam hal pembukuan sesuai standar akuntansi (Solikin, 2020). Pelaku UMKM belum memahami mengenai pembukuan yang sesuai dengan standar, bahkan ada yang belum melakukan penerapan akuntansi sesuai standar seperti belum melakukan pembukuan dan penyusunan laporan keuangan. Pelaku UMKM banyak yang hanya melakukan pembukuan berupa kas masuk dan keluar saja. Hal yang dinilai penting bagi UMKM adalah menghasilkan laba yang besar tanpa repot untuk melakukan pembukuan dan penyusunan laporan keuangan. Padahal laporan keuangan sangat dibutuhkan untuk membantu menganalisis dan mengevaluasi kinerja UMKM.

Selain itu, sebagaimana dicantumkan pada Tabel 1, berdasarkan pengamatan terdapat empat permasalahan yang sering dihadapi oleh UMKM, antara meliputi motivasi untuk membangun rintisan usaha, penggunaan teknologi dan media sosial, sistem dan kebijakan akuntansi, serta penggunaan aplikasi untuk membantu menyusun laporan keuangan. Khusus untuk pemasaran dengan media sosial, hal ini sangat penting karena perkembangan teknologi dan media sosial menuntut UMKM menggunakan media sosial untuk meningkatkan daya saing (Vernia, 2017). Dengan memperhatikan hasil observasi tersebut, kegiatan pengabdian masyarakat ini akan berupaya untuk membantu mengatasi permasalahan yang dihadapi oleh UMKM.

Tabel 1. Permasalahan dan Kegiatan

\begin{tabular}{|c|c|c|}
\hline NO & PERMASALAHAN & $\begin{array}{c}\text { BATASAN KEGIATAN YG AKAN } \\
\text { DILAKUKAN }\end{array}$ \\
\hline 1 & $\begin{array}{l}\text { UMKM rintisan masih membangun } \\
\text { usaha awal dan belum melakukan } \\
\text { pengelolaan usaha dengan layak }\end{array}$ & $\begin{array}{l}\text { Memberikan motivasi usaha, membantu } \\
\text { menyusun stategi bisnis yang tepat, dan } \\
\text { alternatif media pemasaran yang mudah } \\
\text { dijangkau }\end{array}$ \\
\hline 2 & $\begin{array}{l}\text { Belum mengoptimalkan teknologi } \\
\text { dan media sosial untuk mendukung } \\
\text { usaha }\end{array}$ & $\begin{array}{l}\text { Memberikan pelatihan dan pendampingan } \\
\text { dalam memanfaatkan teknologi informasi } \\
\text { untuk menunjang usaha }\end{array}$ \\
\hline 3 & $\begin{array}{l}\text { Belum adanya pemahaman } \\
\text { pentingnya laporan keuangan } \\
\text { sebagai salah satu faktor yang } \\
\text { mendukung kesuksesan usaha }\end{array}$ & $\begin{array}{l}\text { Memberikan pelatihan dan pendampingan } \\
\text { terkait pemahaman laporan keuangan bagi } \\
\text { kesuksesan usaha }\end{array}$ \\
\hline 4 & $\begin{array}{l}\text { Belum terselenggarakannya } \\
\text { pembukuan yang dapat } \\
\text { menghasilkan laporan keuangan }\end{array}$ & $\begin{array}{lll}\text { Mendampingi menggunakan } & \text { aplikasi } \\
\text { sederhana dalam menyusunan } & \text { laporan } \\
\text { keuangan UMKM } & & \end{array}$ \\
\hline
\end{tabular}


Mempertimbangkan masalah-masalah yang dihadapi UMKM tersebut, tujuan dari kegiatan pengabdian masyarakat ini adalah untuk melakukan pendampingan bagi UMKM rintisan dalam menjalankan usaha, memasarkan produknya, dan mencatat transaksi serta menyajikan laporan keuangan sesuai dengan standar akuntansi yang berlaku. Adapun target luaran dari kegiatan pengabdian masyarakat ini adalah: (1) Peningkatan pengetahuan strategi bisnis bagi pengusaha UMKM untuk bertahan dan mengembangkan usaha, (2) Peningkatan pemahaman pengusaha UMKM atas pemasaran produk secara daring dengan memanfaatkan media sosial, dan (3) UMKM rintisan mampu menyusun laporan keuangan UMKM menggunakan aplikasi Lamikro.

\section{METODE PELAKSANAAN}

Kegiatan ini dilaksanakan bekerja sama dengan Yayasan JARI (Jejaring Alumni dan Returning Expert Indonesia) dengan menyasar pengusaha UMKM rintisan. Tiga tahap dalam pelaksanaan pengabdian ini adalah tahap persiapan, tahap bimbingan teknis, dan tahap pendampingan. Pada tahapan persiapan ini dilakukan beberapa kegiatan sebagai berikut: (1) Rapat koordinasi antara dosen pengusul, Pusat Penelitian dan Pengabdian kepada Masyarakat PKN STAN dan Yayasan JARI, (2) Tim Pengmas Dosen melakukan studi pustaka untuk mengetahui kebutuhan pendampingan UMKM, (3) Tim Pengmas Dosen PKNSTAN menyiapkan rencana pendampingan dan materi pendampingan, (4) Tim Pengmas Dosen PKNSTAN menyebarkan informasi pendaftaran lewat media sosial, dan (5) Calon peserta mengisi registrasi.

Dalam proses registrasi, peserta yang merupakan pengusaha UMKM diminta mengisi formulir pendaftaran yang salah satu isiannya adalah tentang masalah-masalah yang mereka dihadapi. Rekapitulasi pertanyaan tertutup pada atas peserta yang mendaftar $(\mathrm{n}=40)$ menunjukkan bahwa sebagian besar responden menyebutkan empat masalah (lihat Gambar 1). Empat hal yang dikeluhkan, yaitu (1) pemasaran online, (2) strategi bisnis, (3) modal, dan (4) pembukuan. Hal ini sejalan dengan pendapat (Riani, 2011), yang melihat permasalahan UMKM di Bukittinggi terdiri dari pendidikan pemilik, manajemen tradisional, terbatasnya pangsa pasar dan akses ke permodalan. Topik satu sampai dengan ketiga akan diatasi dalam pengamas ini. Masalah yang ketiga yaitu permodalan tidak akan diatasi pada pengabdian masyarakat kali ini dan dapat dipertimbangkan sebagai topik pengabdian masyarakat berikutnya.

\section{Gambar 1. Hasil Rekapitulasi Masalah Peserta}

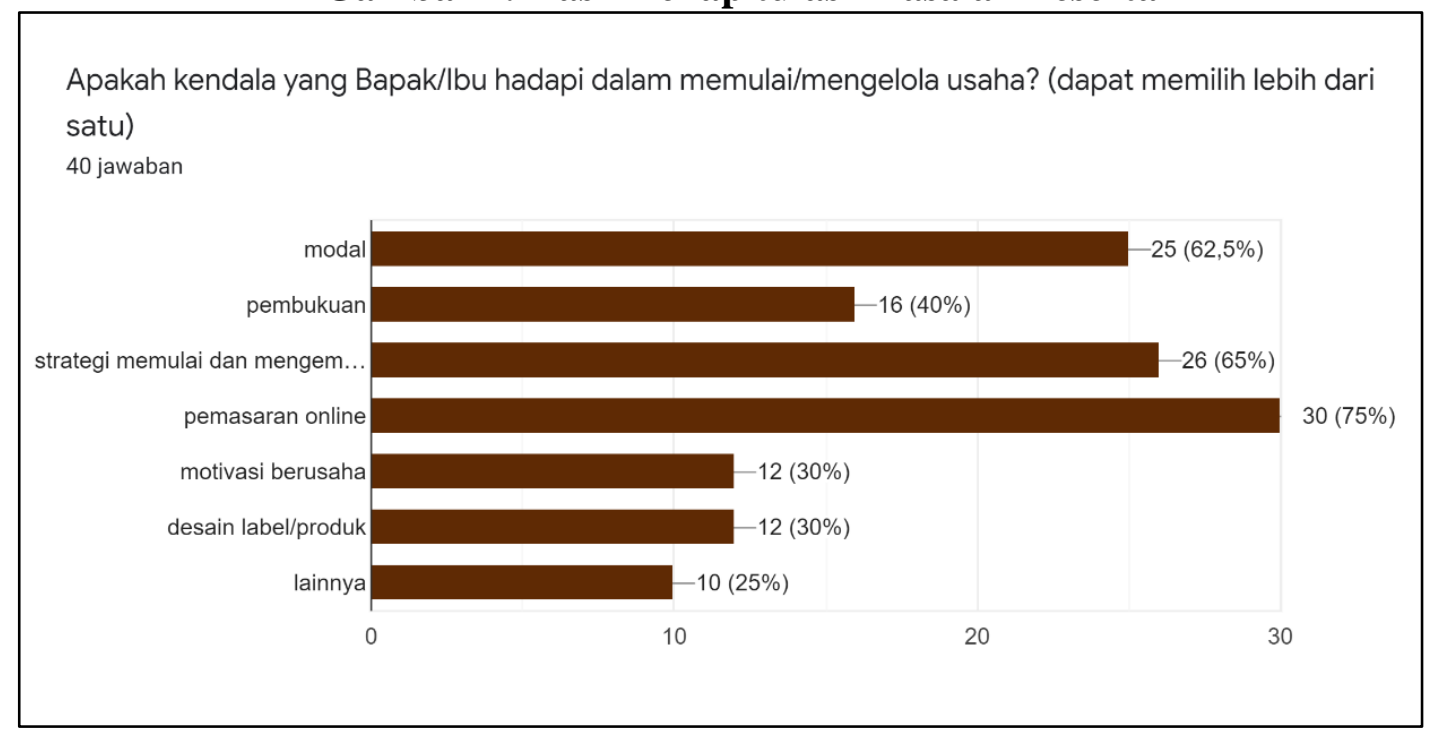

Sumber: Penulis 


\section{PENGMASKU}

Volume 1 No. 2, Desember 2021

Untuk menjawab permasalahan yang dihadapi pengusaha rintisan UMKM, Tim Pengabdian kepada Masyarakat PKN STAN dalam tahap berikutnya mengadakan bimbingan teknis secara daring lewat Zoom. Tim menawarkan solusi atas tiga permasalahan yang dihadapi UMKM rintisan dengan meningkatkan pemahaman pengusaha pemula terkait strategi bisnis, pemasaran dengan media sosial, dan akuntansi dan penyusunan laporan keuangan lewat Aplikasi Lamikro. Khusus untuk penyusunan laporan keuangan, terdapat beberapa alternatif aplikasi untuk pencatatan dan penyusunan laporan keuangan, misalnya dengan Microsoft Excel (Firmansyah et al., 2021), si APIK (Dinarjito et al., 2021; Sumiyati \& Akbar, 2020) dan Lamikro (Sumiyati \& Akbar, 2020). Aplikasi ini relatif sederhana (Sumiyati \& Akbar, 2020) dan cocok dipergunakan oleh UMKM rintisan.

Pada tahap ketiga, untuk menindaklanjuti bimbingan teknis, juga dilakukan pendampingan lewat media sosial yang dilakukan selama satu bulan. Pendampingan lewat medsos dilakukan dengan membuat Grup Whatsapp Rintisan UMKM untuk melakukan pemantauan dan penyelesaian kendala yang dihadapi. Salah satu pertimbangan yang diperhatikan adalah memanfaatkan teknologi dan pencatatan sederhana yang mudah dipahami, familiar, dan memungkinkan pengguna untuk memodifikasi sesuai keperluan masing-masing.

\section{HASIL DAN PEMBAHASAN}

Kegiatan utama dalam bentuk webinar Rintisan UMKM via Zoom dan pendampingan lewat grup Whatsapp. Webinar dilaksanakan pada tanggal 27 November 2021 dengan susunan acara terdiri dari empat materi pokok. Materi pertama adalah sharing pengalaman usaha dari pendiri PT Logos Indonesia yang menjelaskan tentang perkembangan usaha logistik PT Logos Indonesia, tips bagi pengusaha pemula, serta motivasi untuk tidak mudah menyerah. Materi berikutnya adalah Strategi Bisnis UMKM, yang menjelaskan tentang motivasi berusaha, jurus sukses bisnis bagi pemula, business canvas model (BMC), dan strategi inovasi. BMC digunakan sebagai alat utama untuk menyusun strategi, karena ternyata alat analisis ini juga dapat diterapkan untuk UMKM, sebagaimana dilakukan oleh Hidayat dan Aprilani (2018).

Materi dilanjutkan dengan strategi pemasaran lewat media sosial. Topik ini penting untuk membekali rintisan UMKM tentang pentingnya media sosial sebagai peluang memperluas pasar (Khusnaini \& Wibowo, 2020). Topik terakhir adalah Tutorial Lamikro, yaitu suatu aplikasi akuntansi sederhana untuk UMKM yang dikembangkan oleh Kementerian Koperasi dan UKM. Materi tentang penyusunan laporan keuangan dengan Lamikro merupakan materi bimbingan teknis berikutnya. Bimbingan dimulai dengan penjelasan tentang persamaan akuntansi, serta tata cara mengunduh dan mengisi data UMKM pada Lamikro. Tahap berikutnya menjelaskan cara menjurnal, misalnya transaksi untuk mencatat modal, membeli bahan, mencatat persediaan, membayar tenaga kerja, membeli kemasan, menjual produk secara tunai maupun kredit, mengambil modal, menerima pembayaran piutang, dan mencatat penyusutan peralatan. Untuk mencatat penjualan produk, peserta dikenalkan dengan menghitung biaya produksi, dan untuk mencatat penyusutan peserta dikenalkan dengan cara menghitung beban penyusutan. Selain itu, peserta juga dipahamkan mengenai laporan keuangan yang disusun tersebut.

Pendampingan dilakukan selama sebulan sejak webinar dilaksanakan. Topik yang dibahas dalam kegiatan pendampingan sesuai dengan topik webinar, yaitu strategi bisnis, pemasaran online, dan akuntansi dengan Lamikro. Diskusi dilakukan lewat whatsapp grup dengan materi dan topik sesuai kebutuhan. Jika diperlukan, fasilitator akan memantik diskusi dengan memposting profil usaha peserta.

Setelah kegiatan bimbingan teknis pada tanggal 27 November 2021, dilakukan evaluasi dengan mengedarkan daftar pertanyaan lewat gform. Pertanyaan-pertanyaan yang digunakan merupakan replikasi dari Khusnaini dan Wibowo (2020). Dalam rangka menafsirkan kondisi 
penilaian tiap pernyataan, dilihat dari rata-rata skor jawaban dari setiap indikator untuk kemudian dilakukan pengelompokan berdasarkan kriteria penafsiran (lihat Tabel 2). Hasil tabulasi $(\mathrm{n}=17)$ dapat dilihat pada Tabel 3 dan Tabel 4.

Secara umum, peserta menilai dan berpendapat bahwa pelaksanaan Webinar dan Bimbingan Teknis pada Pengmas terkait materi adalah sangat baik. Nilai yang tertinggi, berdasarkan persepsi peserta, bahwa kegiatan penting untuk mengembangkan bisnis dan memberikan kesadaran bahwa pemasaran selama ini belum optimal. Hasil evaluasi yang tinggi tersebut diharapkan berhubungan erat dengan peningkatan pengetahuan peserta atas tiga topik yang disampaikan pada bimbingan teknis.

Tabel 2. Klasifikasi Penafsiran Penilaian atas Pertanyaan

\begin{tabular}{ccl}
\hline NO & RATA-RATA SKOR & \multicolumn{1}{c}{ PENAFSIRAN } \\
\hline 1 & $4,21-5,99$ & Sangat Baik \\
\hline 2 & $3,41-4,20$ & Baik \\
\hline 3 & $2,61-3,40$ & Cukup Baik \\
\hline 4 & $1,81-2,60$ & Kurang Baik \\
\hline 5 & $1,01-1,80$ & Tidak Baik \\
\hline
\end{tabular}

Tabel 3. Statistik Deskriptif Pada Pernyataan Atas Materi

\begin{tabular}{llll}
\hline \multicolumn{1}{c}{ PERNYATAAN } & $\begin{array}{c}\text { SKOR } \\
\text { RATA- } \\
\text { RATA }\end{array}$ & KATEGORI & \multicolumn{1}{c}{ INTERPRETASI } \\
\hline $\begin{array}{l}\text { Jelas, menarik, dan } \\
\text { mudah diikuti }\end{array}$ & 4,59 & Sangat baik & $\begin{array}{l}\text { Materi dirasa menarik bagi peserta. } \\
\text { Cukup banyak peserta yang menyatakan } \\
\text { mengerti materi }\end{array}$ \\
\hline $\begin{array}{l}\text { Sesuai dengan yang } \\
\text { diharapkan dan } \\
\text { dibutuhkan }\end{array}$ & 4,76 & Sangat baik & $\begin{array}{l}\text { Peserta merasakan ilmu dan informasi } \\
\text { yang diharapkan sangat sesuai dengan } \\
\text { harapan dan butuhkan }\end{array}$ \\
\hline $\begin{array}{l}\text { Penting untuk } \\
\text { pengembangan bisnis }\end{array}$ & 4,82 & Sangat baik & $\begin{array}{l}\text { Peserta berharap dapat mengikuti } \\
\text { pendampingan lanjutan }\end{array}$ \\
\hline $\begin{array}{l}\text { Banyak materi dan hal } \\
\text { baru yang didapat dari } \\
\text { kegiatan ini }\end{array}$ & 4,76 & Sangat baik & $\begin{array}{l}\text { Materi pembelajaran telah didesain dan } \\
\text { dipersiapkan dengan } \\
\text { mempertimbangkan kebutuhan peserta }\end{array}$ \\
\hline $\begin{array}{l}\text { Kegiatan ini dapat } \\
\text { menyadarkan bahwa } \\
\text { pemasaran pada bisnis } \\
\text { belum optimal }\end{array}$ & 4,82 & Sangat baik & $\begin{array}{l}\text { Peserta menyadari bahwa selama ini } \\
\text { belum optimal dalam melakukan } \\
\text { pemasaran pada bisnisnya }\end{array}$ \\
\hline $\begin{array}{l}\text { Bertekad untuk } \\
\text { mempraktikkan ilmu } \\
\text { yang didapat dari } \\
\text { kegiatan ini }\end{array}$ & & & Sangat baik \\
\hline
\end{tabular}

Sumber: Rekapitulasi penulis, adaptasi Khusnaini \& Wibowo (2020)

Selanjutnya, hasil rekapitulasi evaluasi atas narasumber memberikan hasil yang juga sangat menggembirakan. Penguasaan materi, penyampaian materi, dan penampilan narasumber dinilai sangat baik oleh responden. Dengan indikasi hasil survey persepsi peserta bimbingan teknis terhadap materi dan penyaji, diharapkan bimbingan teknis mencapai hasil yang diharapkan. Formulir evaluasi memang tidak mengevaluasi secara detail tentang hambatanhambatan bisnis yang belum dibahas oleh fasilitator dan pemecahannya.

Masalah-masalah yang ditemukan dalam pelaksanaan dibahas pada pendampingan lewat media sosial. Sebagai contoh, dalam satu sesi diskusi pendampingan dibahas mengenai desain media sosial yang dipergunakan oleh salah satu peserta pelatihan. 
Tabel 4. Statistik Deskriptif Pada Pernyataan Atas Narasumber

\begin{tabular}{lccl}
\hline \multicolumn{1}{c}{ PERNYATAAN } & $\begin{array}{c}\text { SKOR } \\
\text { RATA- } \\
\text { RATA }\end{array}$ & KATEGORI & \multicolumn{1}{c}{ INTERPRETASI } \\
\hline $\begin{array}{l}\text { Narasumber } \\
\text { menguasai materi }\end{array}$ & 4,94 & Sangat baik & $\begin{array}{l}\text { Narasumber memiliki kemampuan } \\
\text { yang memenuhi harapan peserta }\end{array}$ \\
\hline $\begin{array}{l}\text { Menyampaikan } \\
\text { dengan menarik, jelas, } \\
\text { dan terstruktur }\end{array}$ & 4,94 & Sangat baik & $\begin{array}{l}\text { Narasumber menyampaikan materi } \\
\text { dengan susunan yang urut dan mudah } \\
\text { dimengerti }\end{array}$ \\
\hline $\begin{array}{l}\text { Interaksi dengan } \\
\text { peserta sangat } \\
\text { baik }\end{array}$ & 4,88 & Sangat baik & $\begin{array}{l}\text { Narasumber mengundang peserta } \\
\text { untuk terlibat secara aktif dalam } \\
\text { kegiatan }\end{array}$ \\
\hline $\begin{array}{l}\text { Jelas dan tuntas dalam } \\
\text { menjawab pertanyaan } \\
\text { peserta }\end{array}$ & 4,88 & Sangat baik & $\begin{array}{l}\text { Narasumber dapat menjawab materi } \\
\text { pertanyaan yang diperlukan oleh } \\
\text { peserta dengan jelas }\end{array}$ \\
\hline Penampilan & 4,94 & Sangat baik & $\begin{array}{l}\text { Narasumber kegiatan berpenampilan } \\
\text { menarik dan sopan, sehingga menarik } \\
\text { antusiasme peserta }\end{array}$ \\
\hline
\end{tabular}

Sumber: Perhitungan penulis

PENUTUP

\section{Simpulan}

UMKM sangat penting bagi perekonomian Indonesia, baik dari sisi jumlah usaha, peran terhadap PDB maupun dari sisi penyerapan tenaga kerja. Pengabdian masyarakat ini dilakukan untuk meningkatkan keberhasilan UMKM dalam mengembangkan usaha, khususnya dalam kondisi wabah Covid-19. Tiga tahap dilakukan, yaitu persiapan, pelaksanaan bimbingan teknis secara online, serta pendampingan lewat media sosial. Berdasarkan hasil survey terhadap calon peserta, dipilih tiga topik dalam bimbingan teknis, yaitu strategi bisnis, pemasaran dengan media sosial, serta pelaporan keuangan. Dari hasil evaluasi diketahui bahwa peserta menyatakan bahwa materi dan pemateri secara umum sangat baik. Sebagai tindak lanjut, setelah dilakukan bimbingan teknis kemudian dilakukan pendampingan selama sebulan terhadap rintisan UMKM lewat grup whatsapp.

\section{Saran}

Berdasarkan hasil identifikasi masalah yang dihadapi oleh pengusaha rintisan UMKM, salah satu masalah yang dihadapi adalah masalah permodalan. Bahkan, masalah permodalan tersebut menempati urutan ketiga, sebelum masalah pembukuan. Meskipun demikian, pengabdian masyarakat ini belum mengangkat topik tersebut. Pengabdian masyarakat berikutnya dapat mengangkat topik tersebut, khususnya terkait dengan permodalan untuk pengusaha UMKM yang memberikan syarat dan tingkat bunga yang ringan, misalnya Kredit Usaha Rakyat (KUR) maupun Pembiayaan Ultra Mikro (UMi). Selain itu, topik tentang Fintech bagi UMKM (Winarto, 2020) juga merupakan topik permodalan yang perlu diperkenalkan kepada UMKM.

\section{DAFTAR PUSTAKA}

Dinarjito, A., Pratama, A. B., Sitanggang, D., Abrori, F., Alfitra, F. R., Tambunan, L. D., Arfan, M., Muzik, M. R., Hidayat, M. T., Sulfiandra, N., \& Bukit, P. J. (2021). Edukasi dan Pendampingan Penyusunan Laporan Keuangan UMKM Kuliner XYZ. Pengmasku, 1(1), 
$8-13$.

Firmansyah, A., Zulfa, A. M., Prastica, A. E., Nabila, A. A., Aji, A. R. P., Lukyani, C. H., Amallia, E. N., Arifah, L., Andi, M. R., Dewi, N. W. P., Wijaya, R. D., \& Krisabel, T. T. (2021). Edukasi Akuntansi dan Pelaporan Keuangan UMKM X di Era Pandemi Covid19. Pengmasku, 1(1), 1-7.

Hertina, D., Hendiarto, S., \& Wijaya, J. H. (2021). Dampak Covid-19 Bagi UMKM di Indonesia Pada Era New Normal. Jurnal Pengabdian Dharma Laksana Mengabdi untuk Negeri, 3(2), 110-116.

Hidayat, M. T., \& Aprilani, D. (2018). Penerapan Business Model Canvas Sebagai Alternatif Strategi Bisnis Pada UMKM Home Industri Kerajinan Gerabah Erri Art. Economic Education and Entrepreneurship Journal, 1(1), 31-46. http://ejournal.unp.ac.id/index.php/tingkap/article/view/11/11

Kemenkop UKM. (2021). Data UMKM. https://kemenkopukm.go.id/dataumkm/?J32BMs034vuT8I4dk2bfGzYv13r9dsfmlXoxGerBPcUOlPrLHI

Kemenkop UKM (2020). Realisasi Program Pemulihan Ekonomi Nasional UMKM dan Banpres Produktif. https://kemenkopukm.go.id/read/realisasi-program-pemulihanekonomi-nasional-umkm-dan-banpres-produktif

Khusnaini, \& Wibowo, O. (2020). Mengembangkan Pemasaran UKM Kreatif di Tangerang Selatan Melalui Social Media Marketing. Abdi Laksana: Jurnal Pengabdian Kepada Masyarakat, 1(1), 56-64.

Purwanto, N. P. (2020). Bantuan Fiskal untuk UMKM Pada Masa Pandemi Covid-19. Info Singkat Bidang Ekonomi dan Kebijakan Publik, 12(17), 19-24.

Riani, N. Z. (2011). Identifikasi Permasalahan dan Kerangka Pengembangan Kluster UMKM Sandang di Bukittinggi Sumatera Barat. Tingkap, 2(1), 51-64. http://ejournal.unp.ac.id/index.php/tingkap/article/view/11/11

Solikin, A. (2020). Peningkatan Pengetahuan SAK EMKM Dua Usaha Kecil di Kota Jambi dan Kota Banda Aceh. BERNAS: Jurnal Pengabdian Kepada Masyarakat, 1(4), 550-560. https://doi.org/10.31949/jb.v1i4.527

Sumiyati, \& Akbar, M. F. (2020). Pogram Pendampingan Implementasi Sistem Pencatatan Akuntansi Aplikasi Lamikro dan si APIK untuk UMKM di Kota Pangkalpinang. Jurnal Pengabdian Pada Masyarakat, 8(1), 111-126.

Vernia, D. M. (2017). Peranan Pendidikan dan Pelatihan Media Sosial dalam Pemasaran Online untuk Meningkatkan Daya Saing Usaha Mikro Kecil Menengah (UMKM). Lectura Jurnal Pendidikan, 8(2), 193-203.

Winarto, W. W. A. (2020). Peran Fintech dalam Usaha Mikro Kecil dan Menengah (UMKM). Jesya (Jurnal Ekonomi \& Ekonomi Syariah), 3(1), 61-73.

https://doi.org/10.36778/jesya.v3i1.132 


\section{PENGMASKU}

Volume 1 No. 2, Desember 2021

Lampiran. Tangkapan Layar Penyampaian Materi oleh Fasilitator
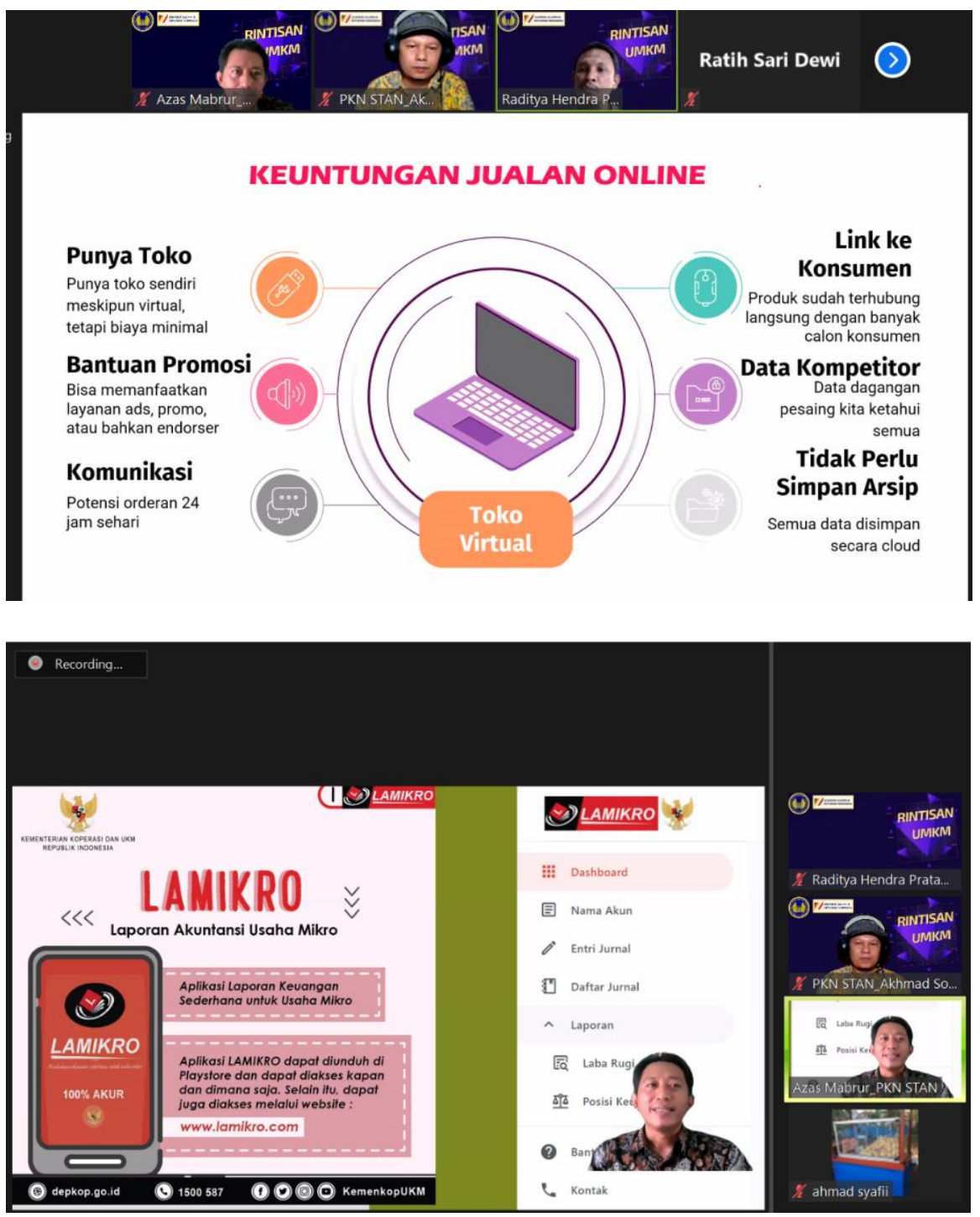